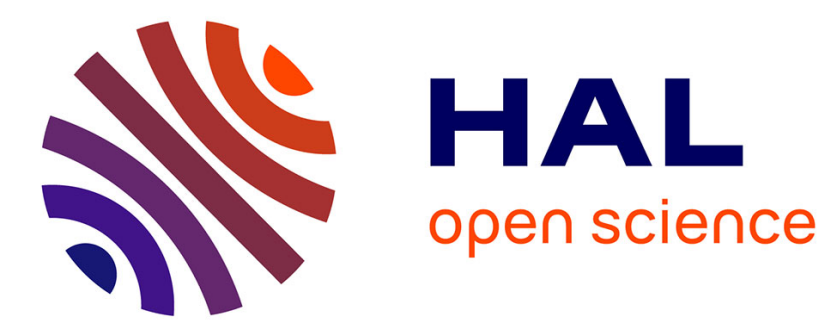

\title{
Characterizing pyroregions in south-eastern France
}

\author{
T. Curt, T. Fréjaville, C. Bouillon
}

\section{To cite this version:}

T. Curt, T. Fréjaville, C. Bouillon. Characterizing pyroregions in south-eastern France. Advances in Forest Fire Research. Chapter 4 - Fire Risk Assessment and Climate Change, Imprensa da Universidade de Coimbra, pp.1093-1101, 2014, 10.14195/978-989-26-0884-6_119 . hal-01128627

\section{HAL Id: hal-01128627 https://hal.science/hal-01128627}

Submitted on 10 Mar 2015

HAL is a multi-disciplinary open access archive for the deposit and dissemination of scientific research documents, whether they are published or not. The documents may come from teaching and research institutions in France or abroad, or from public or private research centers.
L'archive ouverte pluridisciplinaire HAL, est destinée au dépôt et à la diffusion de documents scientifiques de niveau recherche, publiés ou non, émanant des établissements d'enseignement et de recherche français ou étrangers, des laboratoires publics ou privés. 


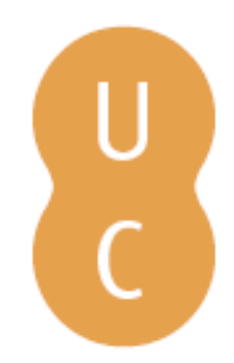

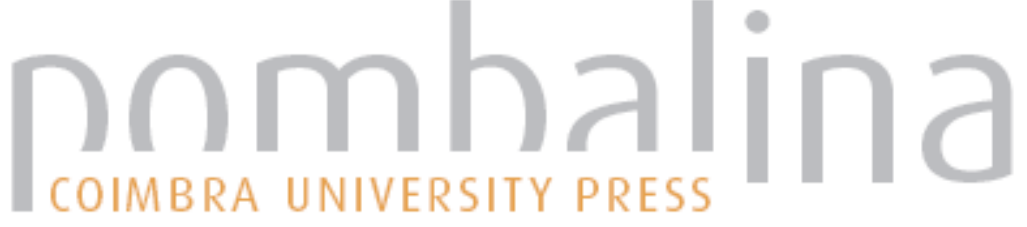

\section{Characterizing pyroregions in south-eastern France}

Autor(es): $\quad$ Curt, Thomas; Fréjaville, Thibaut; Bouillon, Christophe

Publicado por: Imprensa da Universidade de Coimbra

URL

persistente:

http://hdl.handle.net/10316.2/34318

DOI:

http://dx.doi.org/10.14195/978-989-26-0884-6_119

Accessed : $\quad$ 25-Nov-2014 13:07:21

A navegação consulta e descarregamento dos títulos inseridos nas Bibliotecas Digitais UC Digitalis, UC Pombalina e UC Impactum, pressupõem a aceitação plena e sem reservas dos Termos e Condições de Uso destas Bibliotecas Digitais, disponíveis em https://digitalis.uc.pt/pt-pt/termos.

Conforme exposto nos referidos Termos e Condições de Uso, o descarregamento de títulos de acesso restrito requer uma licença válida de autorização devendo o utilizador aceder ao(s) documento(s) a partir de um endereço de IP da instituição detentora da supramencionada licença.

Ao utilizador é apenas permitido o descarregamento para uso pessoal, pelo que o emprego do(s) título(s) descarregado(s) para outro fim, designadamente comercial, carece de autorização do respetivo autor ou editor da obra.

Na medida em que todas as obras da UC Digitalis se encontram protegidas pelo Código do Direito de Autor e Direitos Conexos e demais legislação aplicável, toda a cópia, parcial ou total, deste documento, nos casos em que é legalmente admitida, deverá conter ou fazer-se acompanhar por este aviso. 


\section{ADVANCES IN}

Forest Fire

\section{RESEARCH}

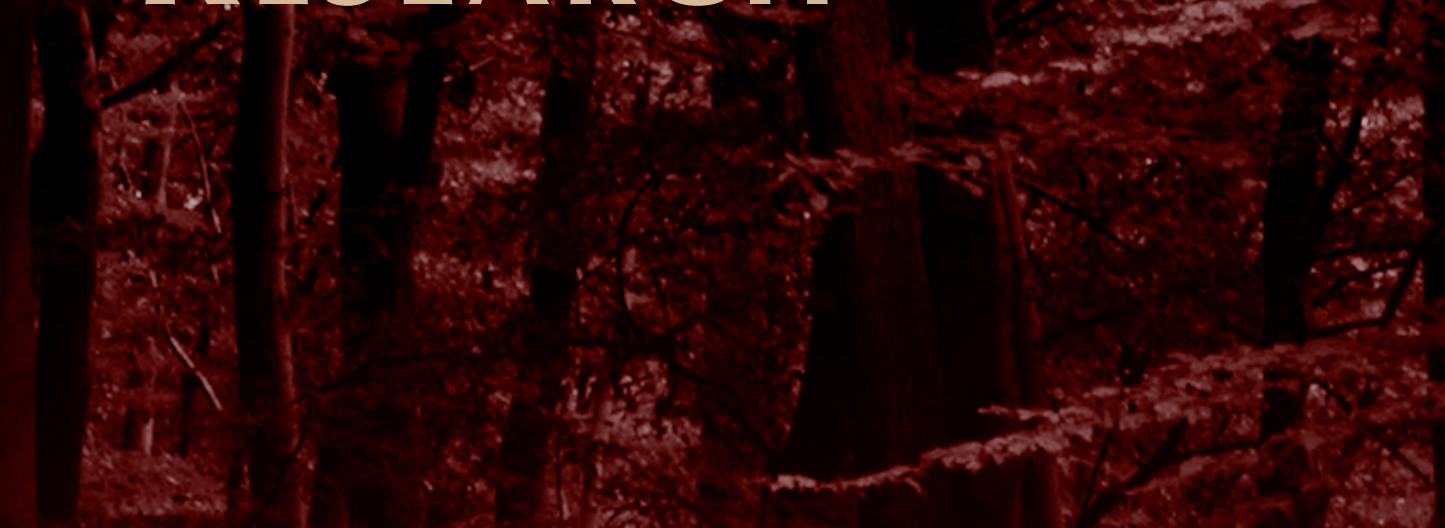

\section{DOMINGOS XAVIER VIEGAS}

\section{EDITOR}




\title{
Characterizing pyroregions in south-eastern France
}

\author{
Thomas Curt, Thibaut Fréjaville' Christophe Bouillon \\ ${ }^{a}$ IRSTEA-EMAX Mediterranean ecosystems and risks, 13185 Aix en Provence (France), \\ thomas.curt@irstea.fr, thibaut.frejaville@irstea.fr, christophe.bouillon@irstea.fr
}

\begin{abstract}
Efficient fire policies may rely on good knowledge of the regional variations of fire activity and of fire drivers. South-eastern France comprises a range of pyroclimates, i.e. regions with contrasted fire activity (from fireprone Mediterranean areas to mountain areas with few fires) and contrasted climate and fire weather. We tested if these pyroclimates also corresponded to specific hierarchy among environmental and human variables which drive fire activity. We used a 1973-2009 georeferenced fire database, and we computed how the landscape compartmentalization, the fuel coverage, the human density and the fire suppression capacity varied at a $2 \times 2$ $\mathrm{km}$ scale. The first pyroregion regroups two maritime fire-prone mountains (Corsica and the maritime Alps) in which there are no clear limitation to fire activity because of high human activity (i.e. numerous ignitions), no fuel limitation, and no weather limitation. The area is especially fire-prone because the suppression capacity is low to medium, and because the compartmented landscape hinders the activity of firemen. In the second pyroregion (fire-prone Mediterranean plains and foothills), fire activity is neither weather-limited (especially during dry summers) nor fuel-limited. It is clearly controlled by fire suppression which is especially active. In the third pyroregion (cool peri-Mediterranean mountains), fire activity remains low in spite of low fire suppression capacity and high landscape compartmentalization, because human activity is low and fire weather is unfavorable on average. We discuss to which extent the present fire suppression strategy (i.e. fast, hard-hitting initial attack on all fires) is adapted to these different pyroregions. In the fire-prone maritime mountains, it would be useful to increase the fire suppression forces. In fire-prone plains and foothills, the current plan of action is well suited, but large and destructive fire may persist due to the climate change and the fuel accumulation. In mountainous areas with low fire activity, fire suppression forces will likely have to adapt to the forecasted increase of fire activity.
\end{abstract}

Keywords: pyroregion; pyrogeography; k-means clustering; fire hazard; France

\section{Introduction}

Wildfires are major disturbances in many terrestrial ecosystems worldwide. In south-eastern France, fires have major impact on humans, infrastructures, and ecosystems (Curt, Borgniet et al. 2013). Basically, wildfire activity and fire regime depend upon three main requirements: sources of ignitions, a fuel to burn (i.e. vegetation and land covers), and a favorable climate and weather acting on fire ignition and propagation (Krawchuk, Moritz et al.2009). The chief drivers of fires are thus: (i) climate which promotes the weather conditions favorable to fire ignition and propagation; (ii) human activities which provide a part of the ignitions, which modify land uses and vegetation, but which also suppress fires; and (ii) vegetation and land uses. The environmental conditions as the topography modify fire propagation. Pyrogeography (sensu (Krawchuk, Moritz et al. 2009) suggests that interactions among these drivers create specific landscape patterns of fire distribution. Here we call 'pyroregion' an area characterized by a typical spatiotemporal pattern of fires driven by a typical hierarchy among fire drivers (weather, fuels, humans).

Characterizing pyroregions is crucial for fire science and fire policy. Actually, it can help understanding the contribution of each fire driver from past to present. The fire policy and the fire suppression strategy may thus adapt to the regional variations of fire regime.

The south-eastern part of France is a good study case because it comprises a range of regions with different fire activity, and presumably different hierarchy among fire drivers. A simple view of the 1973-2009 fire maps shows that fire size, fire pattern, and fire number varies strongly within study 
area (Figure 1). The southernmost part of this area comprises Mediterranean-type ecosystems which are especially fire-prone. The peri-Mediterranean areas have less summer fires but more prescribed burning in winter and spring (Fernandes, Davies et al. 2013). The mountain areas (southern French Alps, Eastern Pyrénées and Massif Central) are less fire-prone but some of them have experienced increased fire activity during the last decades. A precedent study (Fréjaville \& Curt, this issue) partitioned the south eastern France into pyroclimatic regions based on spatiotemporal patterns of fire and climate. We tested to which extent these pyroclimatic regions also corresponded to specific hierarchy in the environmental and human drivers, including fire suppression.

\section{Methods}

In this study we characterized how areas characterized by similar fire regime, climate and similar temporal trend (i.e., pyroclimatic regions) depicted hierarchy in environmental and human drivers throughout southern France, i.e. what are the pyroregions. For this purpose we used a georeferenced fire database (1973-2009), and data on human activities, fuels, weather, and topography.

\subsection{Study area}

The study area was the whole south-eastern France (ca. 80,500 $\mathrm{km}^{2}$ ), including the 15 departments most frequently subjected to wildfires. This area has varied rates of coverage by flammable fuels such as forests and shrublands (15 to 70\%). The main forest types are oaks forests (Quercus ilex, $Q$. pubescens), pine forests (Pinus halepensis, P. sylvestris, P. nigra, P. pinaster), and mixed oak-pine forests. At higher elevation, forests comprise Larix decidua, Fagus sylvatica, Abies alba, Picea abies, and Pinus cembra. Flammable shrublands (so-called garrigues and maquis) are common in the southernmost part of the study area. They are dominated by Quercus coccifera, Ulex parviflorus, Cistus spp., and Erica arborea. At high elevation, the dominant shrubs are Vaccinium myrtillus and Arctostaphyllos uva-ursi. The study area covers a large gradient of elevation from the sea level to the subalpine ecosystems of the French Southern Alps (ca. $2500 \mathrm{~m}$ asl).

The southern part of the study area along the Mediterranean sea has typical Mediterranean climate with hot and windy summers which favor fire activity. The peri-Mediterranean area has a supraMediterranean climate with hot summer temperature but cold winters, and the mountain climate of the French Alps is typically cold in winter and cool in summer.

Wildfire activity heterogeneously impacted the ecosystems and the landscapes in the study area (Figure 1), with a clear gradient from the highly fire-prone coastal areas located near the Mediterranean sea, to peri-Mediterranean mid-elevation mountains which experience frequent fires, then to subalpine mountains which historically experienced fires but at much lower frequency and intensity (Genries, Mercier et al. 2009). Fire is a major driver of vegetation dynamics in the Mediterranean part of the study area: about 6\% of the wildland being has burned at least once between 1960 and 2011. In this area, stand-replacing fires are predominant and mostly occur in summer (Curt, Borgniet et al. 2013). Fire is also frequent in the peri-Mediterranean area all along the coast. Mountain areas (notably subalpine areas of the Pyrenees and Alps) experienced quite frequent fires along the Holocene but these fires were mostly surface fires. All the study area is under the protection of the fire suppression crews and services, but regional variations in fire suppression means exists (see below 2.6). 


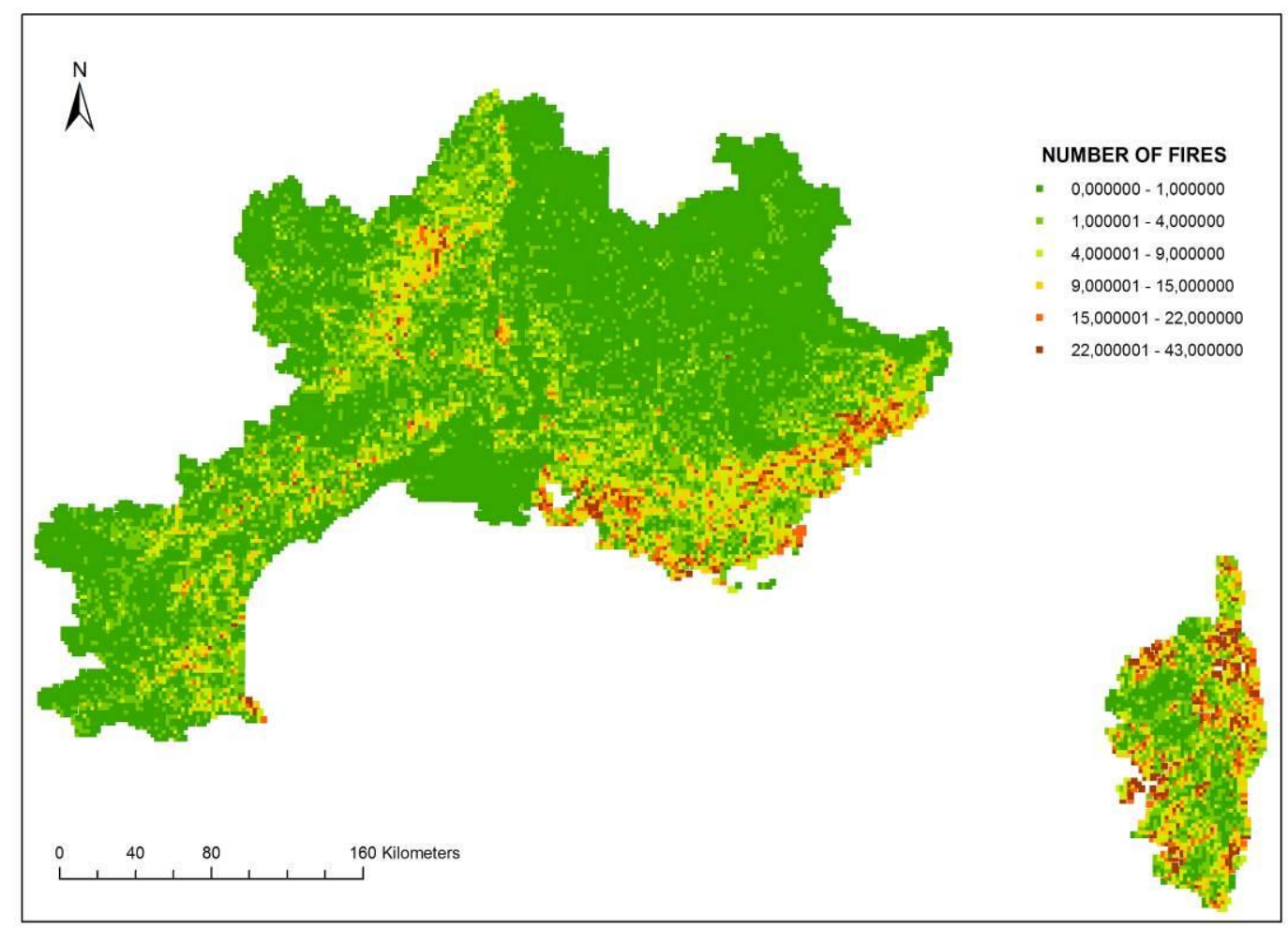

Figure 1. Fire density in south-eastern France (number of fire from 1973 to 2009)

\subsection{Fire Data}

We used the French Prométhée fire database (Prométhée 2011) which gathers all wildland and forest fires and indicates their date, hour, size, and location on a $2 * 2 \mathrm{~km}$ grid since 1973 . We analyzed data for the 1973-2009 period. Fire activity was characterized by three variables: fire density was computed as the number of fires recorded in a $2 * 2 \mathrm{~km}$ pixel, the burned area computed as the total area burned in each pixel (calculated as the sum of all individual fires), and the fire length season which was calculated as the number of days during which fires occurred in a given year in each pixel along the 1973-2009 period.

\subsection{Fire Weather}

We used the fire weather index (FWI) and its sub-indices (FFMC, DMC, DMC) to assess the mean weather during a fire event, which is crucial for explaining its size and pattern. The FWI is a unitless index that was designed originally to forecast fire risk in Canada on the basis of past and current weather conditions (van Wagner 1987) including air temperature and relative humidity, surface wind speed, and rainfall in the past 24 hours. It provides a uniform, numeric method of rating fire danger throughout an area (Aguado, Chuvieco et al. 2003). The FWI aims to predict the probability and ease of ignition and propagation of a fire on the forest floor, taking into account the weather conditions. High FWI values indicate high fire danger.

\subsection{Land covers and fuels}

The type of land cover may affect the propensity to burn because all land covers do not have the same flammability, and because some land covers are preferentially burned for agricultural purpose or other purposes. The main types of land covers have been assessed using the CORINE 2006 database. We 
regrouped the land uses in main categories including forests (pine, oak, and mixings), shrublands, pastures, agricultural lands, urban lands, and other types such as lakes and rivers.

It is of importance to assess the fuel coverage in each pixel of the study area. For this purpose we transformed the CORINE land covers (see above) into flammable fuels (forests, shrublands, and pastures) and non-flammable fuels (i.e. all other types of land cover). Each pixel was assigned a value of fuel coverage computed using a fuel connectivity index for the 8 adjacent pixels. If the central pixel and the 8 adjacent pixels comprised flammable fuels, the fuel coverage was coded as 1 , and coded as 0 if fuel was absent from all pixels. Increasing values of fuel coverage suggest higher contagion of flammable vegetation.

\subsection{Topography}

Topography is acknowledged to affect the likelihood of fire ignition but mostly the behavior of fire (Pyne, Andrews et al. 1996). Flat landscapes promote rapid fire rate of spread and large, regular fire shapes while heterogeneous landscapes make fires contours more heterogeneous and generally result in smaller fires. Southern aspects generally favor ignitions and fire propagation since fuels may be drier. Slopes oriented towards dominant summer winds would also favor fire propagation. We assessed three main topographic variables for each pixel: slope, aspect, and a synthetic index of landscape complexity. This index is oriented towards the determination of the extent to which landscape is compartmented and how this may affect fire propagation and size, and the activity of firemen. Actually, a compartmented landscape with steep slopes, deeps valleys, variations of aspect, ridges would both limit fire extension but also hinder the work of firefighters (Pyne, Andrews et al. 1996). This index was computed as the cumulated absolute differences in elevation and aspect between each pixel and the eight surrounding pixels. High values of the index of complexity suggest complex fire contours and high difficulty for fire suppression.

\subsection{Human activities}

Humans have two contradictory incidences on fires. First, they provide most ignitions as lightning fires remain very likely rare in our study area. Secondly, they also prevent and suppress fires. Human activities strongly impact fire activity since fire is both a natural disturbance but also a tool for vegetation management, and sometimes conflicts. Fire causes were not explicitly considered as this information remained fragmentary until the mid-1990s: less than $50 \%$ of causes really known (Prométhée 2011). We considered the main variables expressing the pressure exerted by humans on fire activity in each pixel: the density of roads, the density of wildland-urban interfaces, and the population density. Indeed, high density of roads, houses and humans likely increases the number of ignitions.

Data from the French firefighting services were used to assess the regional variations in the fire suppression capacity. We computed a synthetic score using different information. First, we assessed the number of fire suppression forces, specific fire suppression material resources (trucks) and mean annual investment in suppression resource for each of the 15 departments of the study area (corresponding to districts of 3,567 to $6,925 \mathrm{~km}^{2}$ ). These data were recoded as scores from 1 (very low) to 5 (very high) according to iso-range values. Secondly, in order to get a more detailed view of the location of the fire suppression forces, we used a georeferenced database of all firehouses. Each firehouse was affected a code according to the number of fire crew $(1=$ low; $2=$ medium; $3=$ high $)$. Then, we computed an inverse distance weighted function from each firehouse, which represents the capacity or the time needed to suppress a fire from each firehouse. Finally, we combined these two sets data to get a map of the score of fire suppression capacity. It indicates the number and location of human and mechanical means that can suppress a fire in any pixel of the landscape, under the assumption that higher and closer fire suppression resources would suppress more effectively fires, and prevent them from becoming large and destructive. 


\subsection{Data Analyses}

A precedent study (Fréjaville \& Curt, this issue) partitioned the south eastern France into pyroclimatic regions based on spatiotemporal patterns of fire and climate (Figure 2). We used this pyroclimatic classification as a basis to test if the different pyroclimates corresponded to specific hierarchies in the environmental and human drivers, including fire suppression. In a first step, we used a principal component analysis (PCA) in order to determine the redundant variables, and to select the most influential environmental and human variables. The fire and climate variables were put as supplementary variables because they were prior used to discriminate pyroclimatic regions. In a second step, we plotted the values of these influential variables as a function of the pyroclimatic groups in order to determine which variables discriminated each pyroclimatic group.

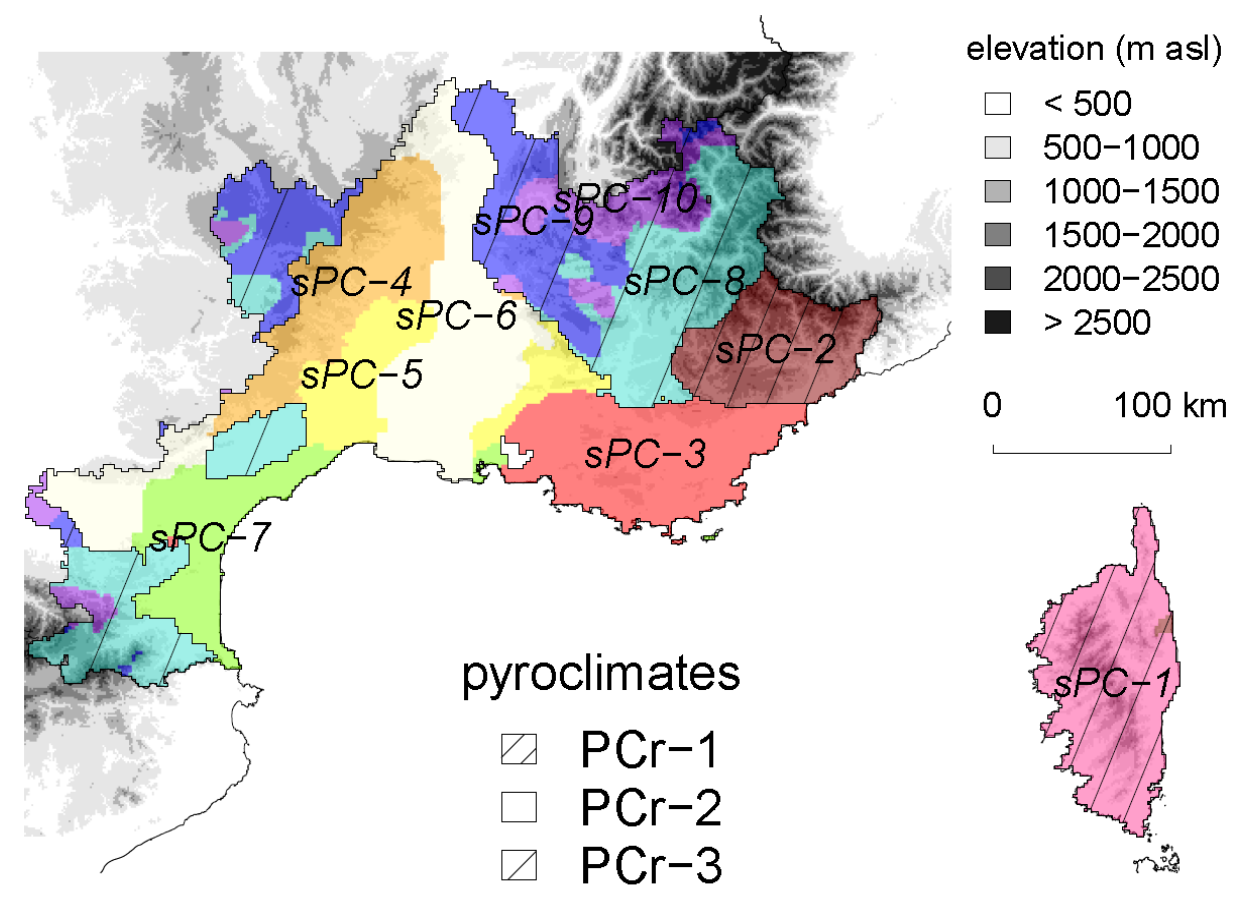

Figure 2. Pyroclimatic regions of south-eastern France. (From Fréjaville \& Curt, see this special issue and Table 1)

Table 1. Main characteristics of the pyroclimatic regions of south-eastern France1973-2009 (From Fréjaville \& Curt, see this special issue)

\begin{tabular}{|c|c|c|c|}
\hline & PCr-1 & PCr-2 & PCr-3 \\
\hline Fire activity & $\begin{array}{c}\text { Maximal fire density } \\
\text { Medium and large fires } \\
\text { Long fire season }\end{array}$ & $\begin{array}{c}\text { High fire density } \\
\text { Small to large fires } \\
\text { Long fire season }\end{array}$ & $\begin{array}{c}\text { Low fire density } \\
\text { Small fires } \\
\text { Short fire season }\end{array}$ \\
\hline Fire activity trend & $\begin{array}{c}\text { Increasing fire density at spring } \\
\text { and autumn }\end{array}$ & $\begin{array}{c}\text { Decreasing fire density and } \\
\text { size in almost all seasons }\end{array}$ & $\begin{array}{c}\text { Increasing fire density in } \\
\text { summer, decreasing fire } \\
\text { size in summer and winter }\end{array}$ \\
\hline Climate & $\begin{array}{c}\text { High summer and winter } \\
\text { precipitation }\end{array}$ & $\begin{array}{c}\text { Hot summer temperature, } \\
\text { high 95 }\end{array}$ & $\begin{array}{c}\text { High spring and summer } \\
\text { precentipitation FFMC } \\
\text { and FWI }\end{array}$ \\
\hline Climate trend & $\begin{array}{c}\text { High increase 95 } \\
\text { and DMC }\end{array}$ & Decreasing FWI in spring & $\begin{array}{c}\text { Increasing summer } \\
\text { temperature, decreasing } \\
\text { winter precipitation }\end{array}$ \\
\hline
\end{tabular}




\section{Results}

The PCA allowed determining the most influential environmental and humans variables, and discarding the redundant variables. Finally, the PCA indicated two main groups of environmental and human variables (Figure 2). The first comprises high fuel coverage, wildland flammable vegetation (predominantly forests and shrublands), and compartmented terrains which are difficult to access. This group corresponded to areas with high mean annual rainfall. At the opposite, the other group corresponded to areas with high human activity (high housing density, high road density), and high capacity of fire suppression. It corresponded to high mean annual temperature and high values of FWI and the associated indices (FFMC, DMC, DC).

\section{Variables factor map (PCA)}

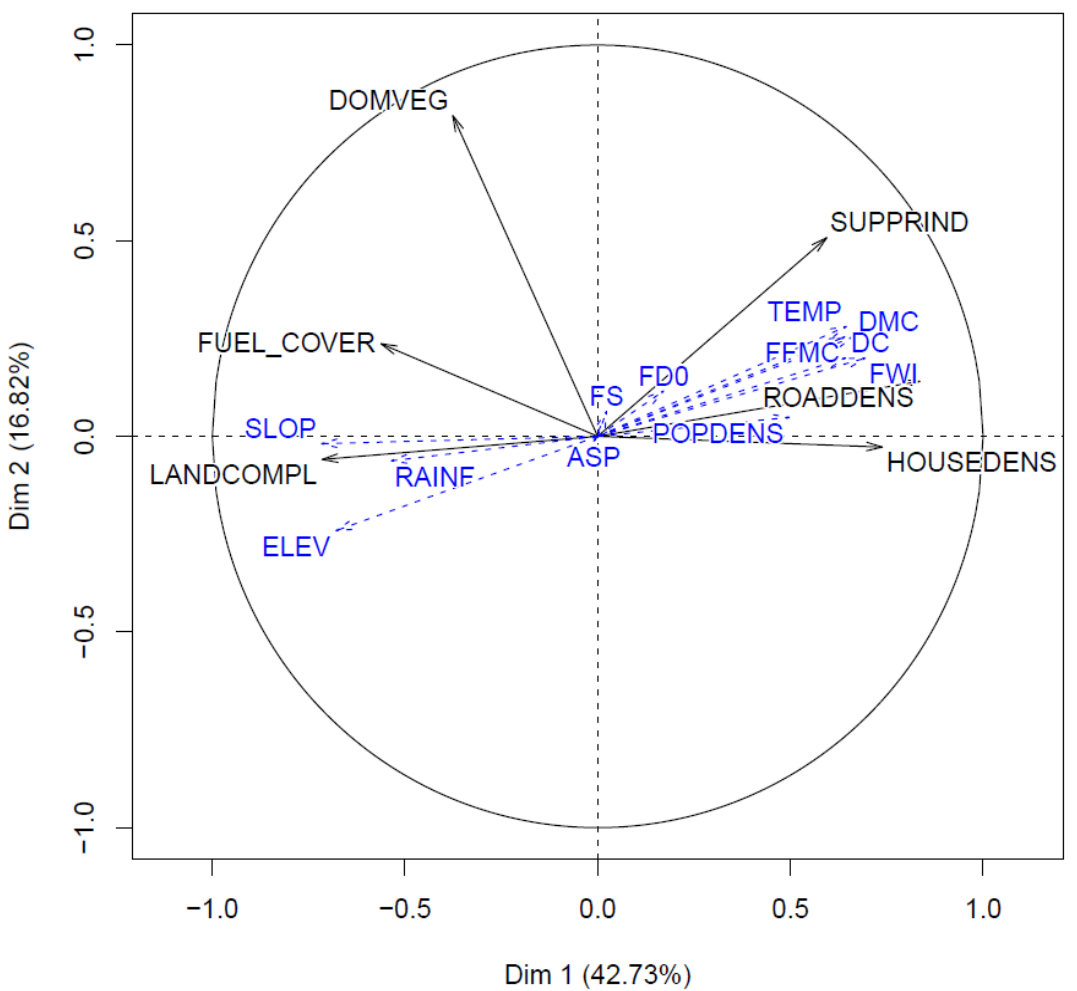

Figure 3. Principal component analysis of the main fire drivers in south-eastern France. Variable in black are active variables (FUEL_COVER: fuel coverage, LAND_COMPL: compartmentalization of the landscape, IND_LUTTE: fire suppression capacity index, Lroute: road density, SUM_Sbati: surface of habitations). Variables in blue are supplementary variables

The comparison of the main environmental and human variables for the three pyroclimatic regions (Figure 4) indicated that the first pyroclimatic region was characterized by a medium to high human activity, a very high fuel coverage and a highly compartmented landscape, but a low to medium fire suppression capacity. The second pyroclimatic region was characterized by high human activity but high fire suppression capacity, a low compartmented landscape, and low fuel coverage. The third pyroclimatic region was characterized by high fuel coverage and highly compartmented landscape but a low human activity and fire suppression capacity. 

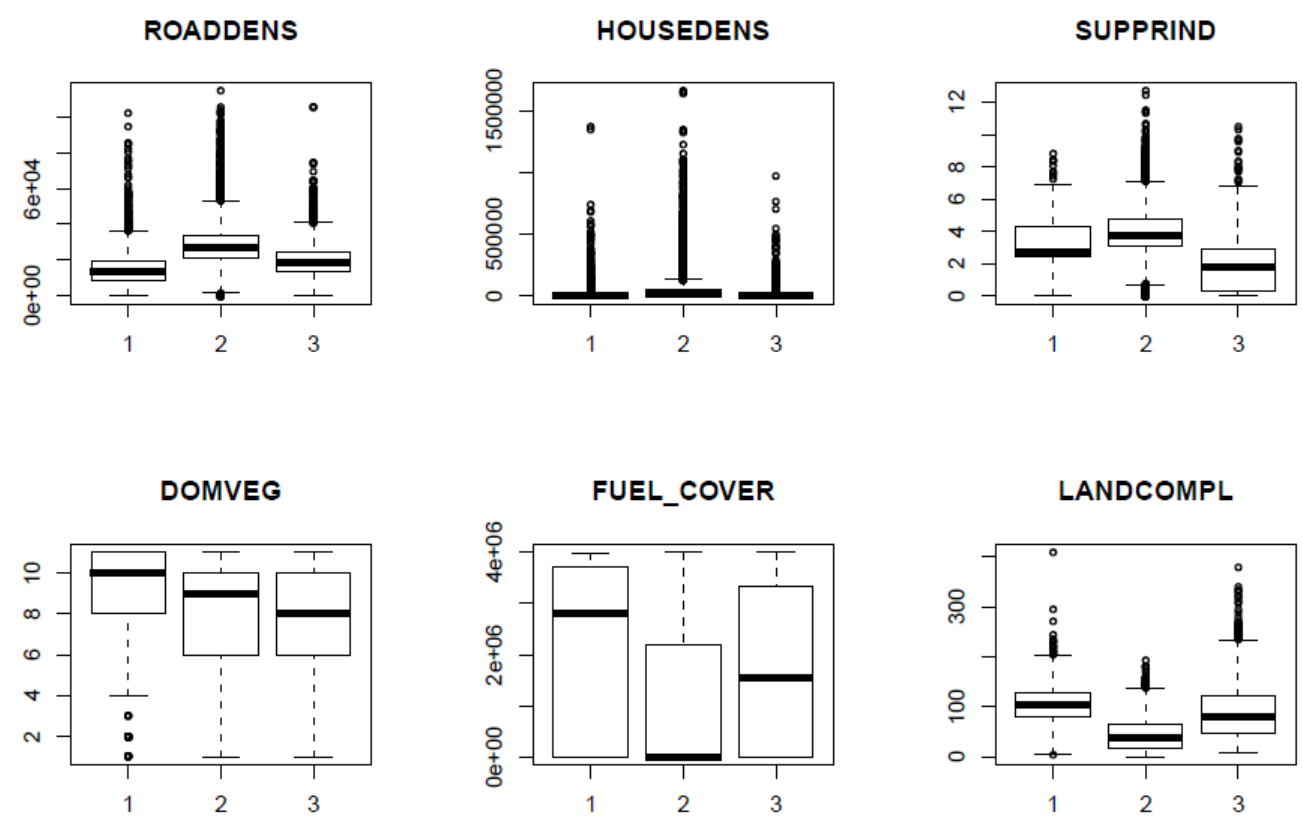

Figure 4. Boxplots of the main fire drivers for the three pyroregions of south-eastern France

\section{Discussion}

\subsection{Pyroregions}

The combination of the pyroclimates regions with human and environmental variables provided a description of three main pyroregions, which all have a specific combination of fire activity, fire weather and climate with specific features of human activity, fuel coverage, land compartmentalization, and fire suppression capacity.

The first pyroregion regroups two maritime fire-prone mountains: Corsica and the maritime Alps. Both areas have high fire density, medium to large fires, and a long fire season. Fire density increased in spring, autumn and winter along the past decades. Climate is favourable to fires and the climate-based fire danger indices increased strongly along the 1973-2009 period (Frejaville et al., this issue. Human activity is strong, fuel coverage is high, the landscape is difficult to access, and the fire suppression fire is low to medium. These maritime mountains have thus many factors conducive to fire, and a limited ability to suppress them. In brief, this pyroregion has a high probability of human-caused ignitions, no major fuel limitation, and no major weather limitation. In addition, the forecasted increases of fire weather indices seem favourable to an extension of the fire season.

The second pyroregion regroups the fire-prone Mediterranean plains and foothills. These areas have medium-to-high fire density, fires of all size, predominantly in summer. Fire weather is characterized by hot summer spells and extreme values of FWI during few weeks in summer. Fire size and fire density have strongly decreased along the recent decades while climate-induced fire danger has increased. This pyroregion has very high human activity and very high fire suppression capacity, low fuel coverage (due to landscape fragmentation) and a low-compartmented landscape. In brief, fire activity is neither weather-limited (especially during dry summers) nor fuel-limited. Fire activity is clearly controlled by fire suppression which is especially efficient and favoured by a relatively flat landscape, and a dense road network. 
The third pyroregion regroups the cool peri-Mediterranean mountains with low fire activity. However, fire density has locally increased during the two past decades in parallel to an increase of annual FWI means and extremes. In this pyroregion, fuel coverage is non-limiting to fire activity. The high landscape compartmentalization and the low fire suppression capacity may favour fires, which are clearly limited by low ignition (due to low human activity) and low by fire unfavourable fire weather in average. Fire suppression means, even low, are likely to be adapted to the present low fire activity.

\subsection{Implications for fire policy}

This study demonstrated that fire activity varies in south-eastern France, in parallel to fire weather, human activity, and fuel coverage. Fire activity and fire drivers vary strongly within a rather small geographic area. Indeed, fuel limitation exists in lowlands dominated by agricultural lands and urban areas while weather limitation exists in mountain environments. A major implication of these findings is that all pyroregions do not require exactly the same fire suppression effort. Fire prevention can be efficiently applied anywhere, but the fire suppression strategy could be adapted to local features.

The present suppression strategy in south-eastern France relies on a fast, hard-hitting initial attack on all fires to prevent them becoming large and destructive. In the highly fire-prone areas, fire prevention is especially active with terrestrial fire patrols, lookout towers, and the regulation of public frequentation in wild-land area during the fire peak season (generally July and August). In addition, specific and reinforced means have been established with the pre-positioning of fire suppression crew at strategic places where fires occur preferentially, a dense network of lookout towers, and fire trackers planes flying during all the peak fire season to detect fires as rapidly as possible. This study suggests that enhancing fire suppression means would help controlling fire activity in the maritime mountains (Corsica and Maritime Alps), which have high fuel loads and compartmented landscapes limiting firemen activity. It should be noted that recent progress has been done for controlling pastoral and agricultural fires during the fire danger peaks. This progress has likely contributed to the recent decrease of fire activity, especially in Corsica. In fire-prone Mediterranean plains and lowlands, fire prevention and suppression is especially active. It has likely strongly contributed to the decrease of fire activity. However, this efficient fire policy can paradoxical effects referred to as the 'fire paradox' (Sande Silva et al. 2011): if fire suppression is effective and reduces the area burned yearly, then wildland fuels accumulate and fuel connectivity increases across the landscape. In turn, this will increase the likelihood of large fires when fire suppression forces cannot control them at the initial stage. In cool peri-Mediterranean mountains, fire activity will likely remain limited but it will likely increase, and fire season will likely expand due to climate change. In the mid-term, it is of importance to increase prevention, surveillance, and the fire suppression capacity in order to prepare to future.

\section{References}

Aguado, I., E. Chuvieco, P. Martin and J. Salas (2003). "Assessment of forest fire danger conditions in southern Spain from NOAA images and meteorological indices." International Journal of Remote Sensing 24(8): 1653-1668.

Curt, T., L. Borgniet and C. Bouillon (2013). "Wildfire frequency varies with the size and shape of fuel types in southeastern France: Implications for environmental management." Journal of Environmental Management 117: 150-161.

Fernandes, P. M., G. M. Davies, D. Ascoli, C. Fernandez, F. Moreira, E. Rigolot, C. R. Stoof, J. Antonio Vega and D. Molina (2013). "Prescribed burning in southern Europe: developing fire management in a dynamic landscape." Frontiers in Ecology and the Environment 11: E4-E14.

Genries, A., L. Mercier, M. Lavoie, S. D. Muller, O. Radakovitch and C. Carcaillet (2009). "The effect of fire frequency on local cembra pine populations." Ecology 90(2): 476-486. 
Krawchuk, M. A., M. A. Moritz, M.-A. Parisien, J. Van Dorn and K. Hayhoe (2009). "Global Pyrogeography: the Current and Future Distribution of Wildfire." PLoS ONE 4(4): e5102.

Prométhée (2011). "La banque de données sur les incendies de forêts en région Méditerranéenne en France." http://www.promethee.com/.

Pyne, S. J., P. L. Andrews and R. D. Laven (1996). "Introduction to wildland fire." 2nd ed. New York, NY: John Wiley \& Sons: 808 pp.

van Wagner, C. (1987). "Development and structure of the Canadian Forest Fire Weather Index

System." Forestry Technical Report - Canadian Forestry Service(No. 35): viii + 37 pp. 